\title{
Electoral Advertising Based on Proximity Marketing
}

\author{
Jessenia Garrido-Martinez ${ }^{1}$, \& Patricio Medina-Chicaiza ${ }^{2,3}$ \\ ${ }^{1}$ Marketing and Business Management Engineer. Universidad Técnica de Ambato, Ambato, Ecuador \\ ${ }^{2}$ Master in Digital Marketing and Electronic Commerce; Master in Information Technology, Pontificia \\ Universidad Católica del Ecuador \\ ${ }^{3}$ Professor of the School of Systems Engineering, Technical University of Ambato; Professor of the Faculty of \\ Administrative Sciences, Ambato, Ecuador
}

Correspondence: Patricio Medina-Chicaiza, Universidad Técnica de Ambato, Ambato, Ecuador. E-mail: ricardopmedina@uta.edu.ec; pmedina@pucesa.edu.ec

Received: July 29, 2019

doi:10.5539/ibr.v12n9p52

\author{
Accepted: August 21, 2019 \\ Online Published: August 26, 2019
}

URL: https://doi.org/10.5539/ibr.v12n9p52

\begin{abstract}
This study seeks to propose a strategy for electoral advertising based on proximity marketing. It arises as a response to the problem detected through direct observation and structured interviews with specialists (experts in electoral marketing, politicians, publicists and ICT leaders) which evidenced the lack of technological tools for electoral advertising such as proximity marketing. In addition, theoretical methods and documentary analysis were used. The results include a proposed strategy with the following phases: search for a supplier, planning, multimedia documents, technological conditions, implementation, control.
\end{abstract}

Keywords: advertising, proximity marketing, electoral campaign

\section{Introduction}

Marketing is fundamental in political development and especially in electoral campaigns. Lindon (1977) states that marketing uses important characteristics, such as motivation - creativity to express the most persuasive advertising issues - and surveys, polls, and tests, to persistently control the performance of advertising campaigns; as well as to promote the ideals of the candidates. Additionally, Galarza (2014), Turban , King, Kyu Lee, Liang, \& Turban (2015) mentions that the media are a fundamental part in the production and dissemination of political communication, stimulating the decision-making process of the voters. That is why the information must be truthful and updated according to the criteria of the political organization or regulatory body.

García Beaudoux \& D'Adamo (2006), Alvarez-García (2010) and Moreno (2012) mention that electoral marketing is an interactive process that involves the transmission of information between politicians, media and voters. Likewise, García-Marbella and Jaimes-Legorreta (2010) establish that electoral campaigns focus on the demands of the voters and consider three important characteristics: the political product, the political organization, and the electoral market, supported by commercial ale techniques that create a visual impact. In addition, Díaz-Jiménez (2015) and Jácome-Santos, Dueñas-Espinoza \& Mera-Alvarez (2015) mention that electoral marketing is a series of actions of political organizations, candidates or interest groups that seek to maximize their electoral performance that develop promotion techniques and financing to persuade and influence their behavior and inform the electorate about the candidate or party.

In addition, Salas \& Jaramillo (2018) say that nowadays transmitting political ideology and having people feel identified with the party and with the authorities that are promoted is also known as political marketing, as well as using techniques such as spots, image campaigns, social networks, direct marketing, branding.

On the other hand, González (2010), Wahab, Wati Osman \& Che Rose (2012), Dushinski (2012) and Palencia (2016) argue that proximity marketing is a tool that exchanges information via Bluetooth, through a mobile telephone in an area or radius of up to 150 meters from the placement of the device or antenna. It is used for sending and receiving images, music, data, audios, and videos which the user decides whether to accept or not. Romanov (2012), Rippetoe, Pitchford \& Zeto III (2012) also state that proximity marketing is known as mobile marketing and is used to send specific wireless messages (audios, texts, videos, images) to each mobile phone user, when they are in a specific place or geographical area through a wireless connection - for example, 
Bluetooth of WiFi- with prior authorization by the receiver. According to Sánchez (2016) and Escandell (2017), this technological tool has been implemented in cinemas, clothing stores, shopping centers and car dealerships such as Mercedes Benz (Madrid).

In Ecuador, elections are held every four years, where governors, regional councilors, provincial prefects and vice prefects, mayors, district and municipal councilors, members of rural parish boards are elected, clearly excepting national elections where the president and vice president of the republic are elected, as detailed in the Code of Democracy according to Art.90 Organic Electoral and Political Organizations Law of the Republic of Ecuador $^{1}$ (2018). In addition to this, according to Art.208, since the call for elections, political organizations may, on their initiative, carry out activities aimed at disseminating their ideological principles, government programs, work plans, and candidacies, provided that it does not imply hiring written press, radio, television, and billboards (Organic Electoral and Political Organizations Law of the Republic of Ecuador, 2018).

The problem, identified by direct observation and bibliographic research, is that for the transmission of electoral advertising conventional media such as radio, television, written press, billboards, posters are used (Pérez-Múnera, 2016) without using communication techniques such as proximity marketing. This leads to ignorance of the use of technological tools that support this activity. Therefore, the direct beneficiaries are the political parties that will transmit their ideology and the candidates as a new way of communicating their proposals to the electors. Meanwhile, indirect beneficiaries are companies dedicated to electoral publishing.

This research aims to develop an electoral advertising strategy based on proximity marketing for a political party and/or another proposal of popular election in Ecuador.

\section{Methodology}

The theoretical methods used were documentary analysis and systematization, which make it possible to organize and extract notable information based on the literature review carried out, which at the same time favored the argumentation on electoral advertising and proximity marketing. Related articles were considered and extracted from the bibliographic search in the databases SpringerLink, Google Scholar, ProQuest, Scopus, E-book, Ebook Central, magazines, international and national scientific events, and studies of national organisms such as the National Institute of Statistics and Censuses (INEC), which regulates statistics and censuses in Ecuador, whose search criteria matched the keywords.

To obtain relevant information, a structured interview was carried out with the campaign directors of the political organizations (specialists) with the purpose of knowing the means used for electoral advertising.

Additionally, direct observation of the use of digital and conventional media was made in the last elections of March 2019 in Ecuador, which evidenced the ignorance of innovative advertising techniques such as proximity marketing.

\subsection{Participants}

The study involved 17 political organizations and movements registered in the National Electoral Council (CNE) in the province of Tungurahua with a political representation of 9.42\% (National Electoral Council, 2019). The capital of the Ambato-Ecuador province, which has a registry of six (6) organizations of which one (1) was discarded due to lack of collaboration in the study, was taken as a reference.

\subsection{Procedure}

The following steps were established after the literature review: First, an inquiry was made about the political parties and movements registered in the province of Tungurahua. Second, a selection of political organizations in force in the city of Ambato was made. Third, six (6) of them were contacted to make a diagnosis through an interview about how they conduct the campaign and the means they use. Fourth, the strategy was designed. Fifth, communication of the proposal.

\section{Results}

An analysis of different authors is presented chronologically on the media used in electoral contests according to each stage provided by the author.

\footnotetext{
${ }^{1}$ Ley Orgánica Electoral y de Organizaciones Políticas de la República del Ecuador
} 
Table 1. Evolution of the media and its electoral process

\begin{tabular}{|c|c|c|}
\hline Author & Characteristics & Means and process \\
\hline $\begin{array}{l}\text { Norris } \\
\text { Pippa } \\
\text { (1997) }\end{array}$ & $\begin{array}{l}\text { Uses a model called } \\
\text { "shopping" } \\
\text { "import-export". } \\
\text { Communication strategies } \\
\text { according to } 3 \text { phases during } \\
\text { the campaign: Pre-modern, } \\
\text { modern and post modern. }\end{array}$ & $\begin{array}{l}\text { Pre-modern } \\
\text { National and local press, local brochures, posters, radio speeches } \\
\text { Modern } \\
\text { Television (main national channels) } \\
\text { Post-modern } \\
\text { Television (fragmented or thematic channels), mailing (sending) of } \\
\text { advertisements (according to selected audience) }\end{array}$ \\
\hline $\begin{array}{l}\text { Martín } \\
\text { Marta } \\
(\mathbf{2 0 0 1})\end{array}$ & $\begin{array}{l}\text { It is based on establishing a } \\
\text { cause-effect relationship of } \\
\text { the political party and } \\
\text { candidates. }\end{array}$ & $\begin{array}{l}\text { Campaign } \\
\text { Newspapers (local and national), television (public and subscription) }\end{array}$ \\
\hline $\begin{array}{l}\text { Quesada } \\
\text { Juan (2005) }\end{array}$ & $\begin{array}{l}\text { Essence in the text and image } \\
\text { to define the political } \\
\text { philosophy of the party and } \\
\text { candidate }\end{array}$ & $\begin{array}{l}\text { Pre-campaign } \\
\text { Meetings, sectoral events, surveys on voter needs } \\
\text { Campaign } \\
\text { Written press (newspapers, local and national magazines), radio, television } \\
\text { (spots, interviews), billboards, posters, brochures, digital media (Fan page, } \\
\text { blogs) }\end{array}$ \\
\hline $\begin{array}{l}\text { Pérez } \\
\text { Carlos } \\
(2016)\end{array}$ & $\begin{array}{l}\text { It is based on strategically } \\
\text { directed advertising according } \\
\text { to the segments analyzed by } \\
\text { the political party. }\end{array}$ & $\begin{array}{l}\text { Pre-campaign } \\
\text { Events with artistic shows (campaign launch and presentation of } \\
\text { conversational candidates), email } \\
\text { Campaign } \\
\text { Mobile telephone services (sending short messages about shocking proposals } \\
\text { daily, monthly, or prior to debates or speeches), radio, television, press, } \\
\text { election campaign vehicles (use in the cars of all party members), billboards, } \\
\text { flyers, posters, leaflets, Internet } \\
\text { Campaign closure } \\
\text { Events in open places or outdoor plazas with artistic shows with messages } \\
\text { about the proposals } \\
\text { Post-campaign } \\
\text { Radio, television (press conference) }\end{array}$ \\
\hline
\end{tabular}

\begin{tabular}{|c|c|c|}
\hline $\begin{array}{l}\text { Rivero } \\
\text { Jesús \& } \\
\text { Huerta } \\
\text { Rodrigo } \\
(2017)\end{array}$ & $\begin{array}{l}\text { It is based on clear, simple, } \\
\text { memorable and credible } \\
\text { communication. } \\
\text { It also focuses on a two-way } \\
\text { communication between the } \\
\text { political party and citizens. }\end{array}$ & $\begin{array}{l}\text { Pre-campaign } \\
\text { Focus Group (know the acceptance of the political party and the future } \\
\text { candidate and needs). } \\
\text { Campaign } \\
\text { Television (spots), radio, banners, newspapers, magazines, brochures, flyers, } \\
\text { billboards } \\
\text { Social networks (Facebook, Twitter, YouTube, Instagram, WhatsApp), web } \\
\text { pages. } \\
\text { "Memes", }\end{array}$ \\
\hline $\begin{array}{l}\text { Hernández } \\
\text { Carlos } \\
(\mathbf{2 0 1 8})\end{array}$ & $\begin{array}{l}\text { It focuses on a strategy known } \\
\text { as todo terreno with } \\
\text { pragmatic political campaigns } \\
\text { (militant-elector). } \\
\text { It is based on electoral } \\
\text { coalition agreements with } \\
\text { partisan militancies. } \\
\text { Uses simple and direct } \\
\text { language. }\end{array}$ & $\begin{array}{l}\text { Pre-campaign } \\
\text { Survey (knowing the needs) } \\
\text { Inter-campaign } \\
\text { Television (presentation of candidates and proposals), radio, press } \\
\text { (interviews), billboards at strategic points } \\
\text { Campaign } \\
\text { Digital media (Exchange of direct information), social networks (Facebook, } \\
\text { Twitter, Instagram, YouTube, WhatsApp), spots (in electronic media from } \\
30 \text { seconds to } 1: 15 \text { minutes), television (debates, spots), mass events } \\
\text { (speeches and gifts) }\end{array}$ \\
\hline
\end{tabular}

Source: own elaboration

With the exposed background, an evolution in the media used within the electoral contests is detailed with the

2 "Meme" is a word used on the Internet to describe an event, material or idea that can be an image, video, music, phrase or joke that is selected or modified, and is transmitted from one person to the next through Internet menas García-Huerta (2014). 
use of traditional media such as television, radio, written press, as well as the use of the internet with digital media or social networks such as Facebook, Twitter, Instagram, WhatsApp, YouTube among others. On the other hand, it is observed that proximity marketing is not used under the characteristics exposed with this type of technological tool.

\subsection{Some Models of Electoral Campaigns}

Perez-Dámazo (2013), García-Beaudoux, D’Adamo \& Slavinsky (2013) and Pérez Múnera (2016) mention that the electoral campaign model with which Tony Saca became president in El Salvador in the 2004 elections and Felipe Calderón Hinojosa in Mexico in the 2006 elections was based on negative spots on television and radio against other political organizations and candidates for the presidency that sought to reduce the credibility of the opponent. With the use of attacks on the principles of morals, capabilities, techniques, structure, history, and performance of the party and candidates during the electoral process, its impact is generated according to the phase of the campaign. If it is used at the beginning, it helps demobilize independent voters. Using it at the end of the election makes it possible to mobilize them favorably because it allows a greater capture of memory.

Additionally, Pérez-Barber (2009), Valdez-Zepeda \& Huerta-Franco (2009), Castro-Martínez (2012) Pérez-Múnera (2016), Maeshima (2018), and Falasca, Dymek \& Grandien (2019) note that Barack Obama, who was elected president in the 2008 elections in the United States, used the broadcast model and the participatory model based on personal contact with the electors plus a campaign called mobile communication with him sending text messages (SMS) to keep all his supporters informed of all activities on a daily and direct basis. He also used e-mail marketing to inform throughout his campaign about his errands, debates, fundraisers or simply send support messages to create a link of trust, also focused on the use of internet and social networks on sites such as: Facebook, Twitter, MySpace, YouTube, blogs and the official website of the candidate, all with their distinctive "Obama" as a brand for advertising within the campaign.

In addition, Slimovich (2017) refers to Mauricio Macri in the campaign that led him to the presidency of Argentina in 2015. His campaign was based on a hybrid model that used conventional media (radio, television, press) and social networks such as Facebook, Twitter, Instagram, Snapchat or YouTube, focusing on advertising strategies through Facebook and Twitter. This makes it easier to segment voters in detail and send ads according to their tastes or interest and thus ensure that the message is of interest. Its characteristic was to seek to maintain direct contact with the citizens. He also implemented "national bell", which involved random visits to Argentinian homes to have a conversation about the problems or needs that they had regarding their place of residence.

In the Ecuadorian context, the investigations of Moreno-Morán (2017) and Parra-Barragán (2018) regarding the presidential campaign of Lenin Moreno in 2017 state that a political communication strategy was used. It focused on the main social networks - Twitter, Facebook, YouTube - as well as traditional media such as press, radio, television (spots) and billboards, regulated by the National Electoral Council ${ }^{3}$ (CNE). Events with artistic shows were also used as well as election campaign vehicles, posters, caps, among others for the broadcast of advertising. It is worth mentioning that, in March 2019, a national electoral process was carried out for various authorities, where the use of strategies similar to President Moreno can be observed.

\section{Preparation and Structuring of the Strategy in Stages}

The following authors were considered in the development of this work: Norris (1997), Martín-Llaguno (2001), Quesada-A (2005), Franco-Marcos \& Dader-García (2009), Ralph F \& James B (2010), Pérez-Múnera (2016), Hassan Salamah (2017), Rivero-Casas \& Huerta-Montiel (2017), Visuri, Hosio, \& Ferreira (2017), Begoña-Gómez (2018), Hernandéz-Alcántara (2018), Hassan (2019), Medina-Chicaiza, García-García, \& Jarrín-Arias (2019), Chaoyong, Chunhong, \& Jie (2019). In that sense, the following phases are presented for the electoral advertising strategy from proximity marketing: provider search, planning, multimedia document characteristics, technological conditions, implementation, control. They are explained below:

\section{Phase 1: Search for a supplier}

A web exploration is carried out, in which a total of 20 proximity marketing providers were found, three (3) of which were contacted through emails and calls via WhatsApp, which facilitated obtaining information about their products and services.

\footnotetext{
${ }^{3}$ Article 115 of the Constitution of Ecuador establishes that the State, through the media, will guarantee in an equitable and equal way the electoral promotion that propitiates the debate and the diffusion of the programmatic proposals of all the candidacies (Consejo Nacional Electoral, 2019).
} 
Table 2. Proximity marketing providers

\begin{tabular}{|c|c|c|c|}
\hline & $\begin{array}{l}\text { SocialWifi } \\
\text { Poland }\end{array}$ & $\begin{array}{l}\text { Seeketing } \\
\text { Spain }\end{array}$ & $\begin{array}{l}\text { Beaconstac } \\
\text { USA } \\
\text { India }\end{array}$ \\
\hline Coverage & $\begin{array}{l}\text { Any country, city or town } \\
\text { in the world that has } \\
\text { internet. You only need to } \\
\text { contact the supplier. }\end{array}$ & $\begin{array}{l}\text { All countries in the world with shipping } \\
\text { charges, taxes and international fees } \\
\text { after hiring }\end{array}$ & $\begin{array}{l}\text { All countries in the world with } \\
\text { shipping charges, taxes and } \\
\text { international fees, for } 24 \text { hours } \\
\text { after purchase }\end{array}$ \\
\hline $\begin{array}{l}\text { Minimum } \\
\text { requirement }\end{array}$ & $\begin{array}{l}\text { Company platform and } \\
\text { Internet }\end{array}$ & $\begin{array}{l}\text { Wireless nodes provided by the } \\
\text { company, you need internet }\end{array}$ & $\begin{array}{l}\text { Beacon Bluetooth does not need } \\
\text { Internet }\end{array}$ \\
\hline Characteristics & $\begin{array}{l}\text { Captive portal } \\
\text { Communication with the } \\
\text { customer } \\
\text { Analytics } \\
\text { Simple page design. } \\
\text { Login in social networks. } \\
\text { Welcome pages } \\
\text { Opinions } \\
\text { Advertising mail } \\
\text { Network monitoring } \\
\text { Remarketing }\end{array}$ & $\begin{array}{l}\text { Customer identification and registration } \\
\text { Analytics } \\
\text { Automation and }{ }^{4} \mathrm{CRM} \text { integration } \\
\text { SMS, WhatsApp campaigns, push } \\
\text { notifications, email } \\
\text { Offline sales and integration cycle, } \\
\text { online } \\
\text { They work with batteries or } 125 / 220 \\
\text { volt power. } \\
\text { Send messages to phones by proximity } \\
\text { with or without APP installed }\end{array}$ & $\begin{array}{l}\text { Transmission of offers at the right } \\
\text { time and the right location } \\
\text { Informing consumers about offers } \\
\text { when they are close to the product } \\
\text { Proximity marketing without } \\
\text { application } \\
\text { Creation of own and easy to use } \\
\text { application } \\
\text { Analytics } \\
\text { Using accumulated data from the } \\
\text { application to personalize the } \\
\text { message }\end{array}$ \\
\hline Software Cost & $\begin{array}{l}\text { Necessary } \\
\text { Small businesses } \$ 450 \text { a } \\
\text { year } \\
\text { Hotels } \$ 450 \text { per year } \\
\quad \text { Companies agree the } \\
\text { price according to } \\
\text { their need. }\end{array}$ & $\begin{array}{l}\text { Necessary } \\
\$ 7690 \text { per year including hardware }\end{array}$ & $\begin{array}{l}\text { Necessary } \\
\text { Basic plan (small and medium } \\
\text { enterprises) } \$ 490 \text { per year } \\
\text { Software Subscription } \\
\text { Premium plan (for companies that } \\
\text { require more control and } \\
\text { advanced capabilities) } \$ 990 \text { per } \\
\text { year. } \\
\begin{array}{l}\text { Reseller plan (for proximity } \\
\text { marketing agencies) } \$ 2990 \text { per } \\
\text { year }\end{array}\end{array}$ \\
\hline Hardware cost & $\begin{array}{l}\text { It is not necessary to make } \\
\text { the purchase of a } \\
\text { hardware you can use a } \\
\text { router or router that you } \\
\text { have while it is } \\
\text { compatible such as: } \\
\text { Cisco, MikroTik, Ruckus } \\
\text { Wireless, Zebra, } \\
\text { OpenWrt, Ubiquiti } \\
\text { Networks, Cisco Meraki, } \\
\text { Aruba to Hewlett Packard } \\
\text { Enterprise company, } \\
\text { Aerohive Networks, } \\
\text { Extreme Networks, } \\
\text { Teltonika, Fortinet. }\end{array}$ & Pack of 10 wireless nodes. & $\begin{array}{l}\text { The purchase of banks is } \\
\text { necessary: } \\
\text { Pocket: } 3 \$ 69 \text { package } \\
\text { USB: } 3 \$ 78 \text { package } \\
\text { Keychain: } 3 \$ 69 \text { package } \\
\text { Outer vests: } 3 \$ 108 \text { package } \\
\text { Interior squares: } 3 \$ 78 \text { package }\end{array}$ \\
\hline Reach & $\begin{array}{l}\text { It depends on the router } \\
\text { you want to install, it may } \\
\text { vary depending on the } \\
\text { hardware. }\end{array}$ & 15,000 sqare meters & $\begin{array}{l}\text { Pocket: signal range } 0.15-50 \\
\text { meters, battery up to one year. } \\
\text { USB: range } 0.15-80 \text { meters, } \\
\text { battery never dies. } \\
\text { Keychain: range } 0.15-25 \text { meters, } \\
\text { battery up to } 5 \text { months. } \\
\text { External vests: range } 0.15-80 \\
\text { meters, battery up to } 2 \text { years. } \\
\text { Interior squares: range } 0.15-80\end{array}$ \\
\hline
\end{tabular}

${ }^{4} \mathrm{CRM}$ or customer relationships management as well, tool that manages strategies according to customer preferences and preferences (Montoya Agudelo \& Boyero Saavedra , 2013) 


\begin{tabular}{|c|c|c|c|}
\hline & & & meters, battery up to 2 years. \\
\hline Payment type & $\begin{array}{l}\text { Monthly } \\
\text { Annual (receive } 15 \% \\
\text { discount for the annual } \\
\text { payment) }\end{array}$ & Annual (Software and Hardware) & $\begin{array}{l}\text { Monthly (software) } \\
\text { Annual (software) } \\
\text { Hardware (one purchase) }\end{array}$ \\
\hline $\begin{array}{l}\text { Method } \\
\text { payment }\end{array}$ & $\begin{array}{l}\text { Credit card, PayPal, Bank } \\
\text { transfer, payment at the } \\
\text { bank }\end{array}$ & Credit cards & $\begin{array}{l}\text { Credit cards: Visa, MasterCard, } \\
\text { American Express }\end{array}$ \\
\hline $\begin{array}{l}\text { Companies that } \\
\text { use it }\end{array}$ & $\begin{array}{l}\text { RedBull, Kontigo, Innogi, } \\
\text { McDonald among others }\end{array}$ & $\begin{array}{l}\text { Carrefour, Movistar, Claro, Inditex, } \\
\text { Santander, among otherss }\end{array}$ & $\begin{array}{l}\text { Google, KFC, Uber, Latam, } \\
\text { among others }\end{array}$ \\
\hline
\end{tabular}

Source: own elaboration

\section{Phase 2: Planning}

Here, the criteria that are planned for the electoral process are established with the support of proximity marketing.

Table 3. Parameters of the planning phase

\begin{tabular}{ll}
\hline Objetive & $\begin{array}{l}\text { Pre-campaign: Issue party philosophy and indicate future candidates } \\
\text { Campaign: Submit candidate profile and proposals }\end{array}$ \\
\hline Strategic place & Headquarters of the political party \\
\hline Content of the message & $\begin{array}{l}\text { Pre-campaign: Information about the philosophy of the political party, candidate } \\
\text { profile (images, videos, audios, text). } \\
\text { Campaign: Proposals of the candidate, agenda of places of next visits (images, } \\
\text { videos, audios, texts) }\end{array}$ \\
\hline Time & Duration of the campaign \\
\hline Responsible for monitoring & Campaign director \\
\hline
\end{tabular}

Source: own elaboration

\section{Phase 3. Multimedia document features}

Audio, image, video and text formats are established for sending advertising to smartphones.

Table 4. Multimedia document features

\begin{tabular}{|c|c|c|c|}
\hline Audio & Image & Video & Text \\
\hline $\begin{array}{l}\text { The formats can be MP3, } \\
\text { MP4, AAC, WAV }\end{array}$ & $\begin{array}{l}\text { Jpg, png or Gif file } \\
\text { Generic banner size of } 468 \times 60 \\
\text { pixels. } \\
\text { Image size } 320 \times 480,300 \times 400 \text {, } \\
300 \times 250 \text { pixels } \\
\text { Use of shocking or funny } \\
\text { images }\end{array}$ & $\begin{array}{l}\text { The formed must be } \\
\text { MPEG- } 4 \\
\text { Duration of } 30 \text { seconds up } \\
\text { to } 1 \text { minute. }\end{array}$ & $\begin{array}{l}\text { Short messages of up to } 120 \\
\text { characters. } \\
\text { Sponsoring Messages. }\end{array}$ \\
\hline
\end{tabular}

Source: Own elaboration

\section{Phase 4: Technological conditions}

This stage shows the scenario that Ecuador has regarding the use of smartphones and internet access. On the other hand, people can exercise their vote in accordance with the provisions of the Organic Electoral Law (2018) according to Art. 11 that states that the vote will be mandatory for Ecuadorians over eighteen, optional for people between sixteen and eighteen years of age, and those over sixty-five years old. 
Table 5. Technological conditions

\begin{tabular}{cccccc}
\hline Age range & Active cellphone holding & People that own a smartphone & Internet use & Access to the internet & $\%$ \\
\hline $\mathbf{1 6 - 2 4}$ & $69.3 \%$ & $57.4 \%$ & $85.2 \%$ & Urbana & 60.4 \\
$\mathbf{2 5 - 3 4}$ & $82.9 \%$ & $62.7 \%$ & $73.9 \%$ & Rural & 39.9 \\
$\mathbf{3 5 - 4 4}$ & $82.9 \%$ & $52.0 \%$ & $59.6 \%$ & & \\
$\mathbf{4 5 - 5 4}$ & $79.0 \%$ & $39.3 \%$ & $44.0 \%$ & & \\
$\mathbf{5 5 - 6 4}$ & $72.6 \%$ & $25.4 \%$ & $27.2 \%$ & & \\
\hline
\end{tabular}

Source: ( National Institute of Statistics and Censuses, 2017)

Table 5 shows the technological conditions in Ecuador: on average, $47.36 \%$ of people between 16 to 64 years of age have a mobile device. Therefore, the necessary elements for the implementation of strategies based on proximity marketing exist.

\section{Phase 5: Implementation}

Below is a step implementation model:

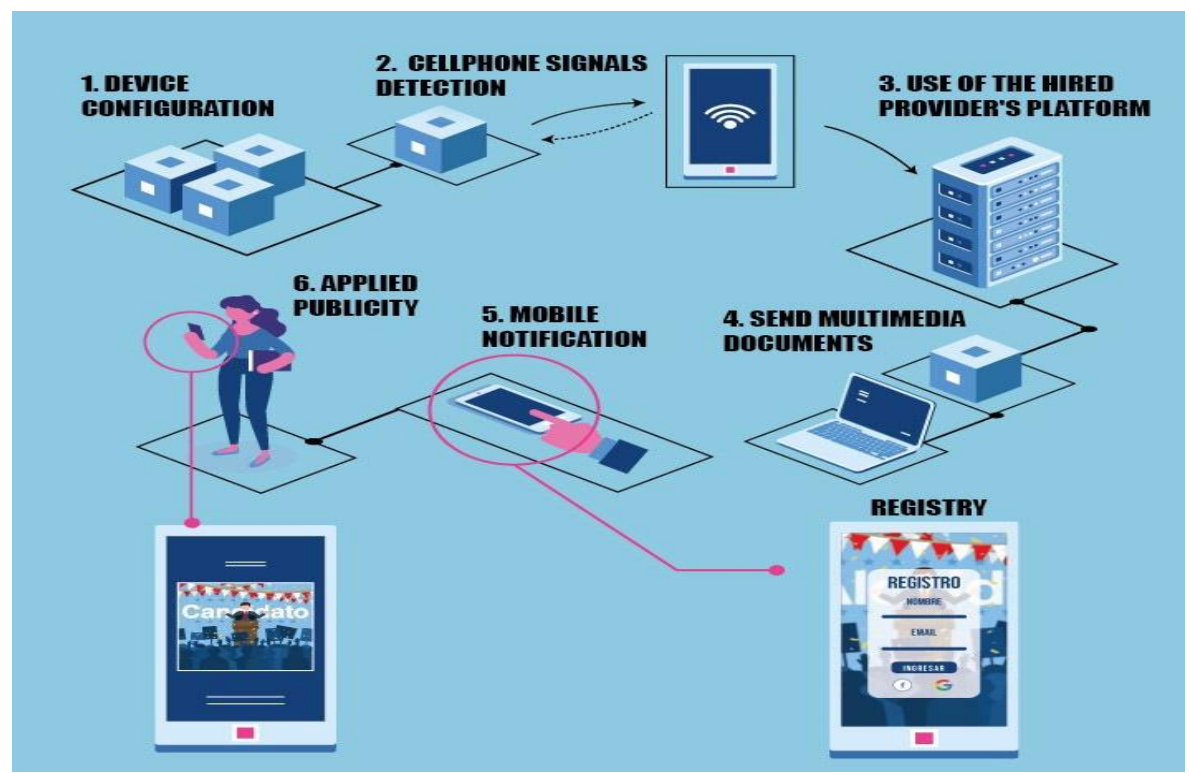

Figure 1. Steps of sending and receiving advertising

Source: Own elaboration

Step 1: Configuration of the device for sending multimedia documents (image, video, audio). Then, the place for the placement of the device in the political headquarters or another site is defined. 


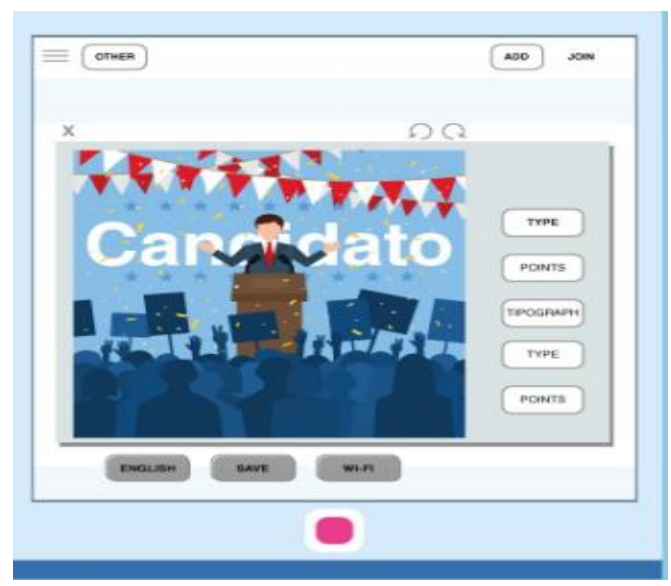

Figure 2. Platform configuration

Source: own elaboration

Step 2: Detects the signals, then sends the message that shows a pop-up window for registration. Thus, a database is also created that will allow segmenting, and then add advertising via email to the election campaign. Finally, the user receives the advertising on their smartphone.

\section{Phase 6: Control}

The control will be carried out throughout the electoral process: pre-campaign, campaign, and end of the campaign, through evaluation processes to verify if the publicity has the expected impact and if it adequately transmits the proposals, philosophy of the candidate among others.

The validation of the preparation of the strategy was carried out through interviews with specialists in the area. Ten (10) experts with more than five (5) years of experience in the labor and academic field were selected. Five (5) campaign directors (expert in electoral and political marketing) of different political parties in the country, three (3) multimedia designers (publicists) and two (2) ICT managers, participated, who from their experience and academic knowledge verified the applicability of the proposal with the determined conditions.

\section{Conclusion}

Based on the literature review found, it is concluded that in the electoral process the candidates carry a campaign model based on traditional media such as television, radio, and press. However, currently, the digital era has allowed the use of unconventional media such as social networks, forming a more direct and communicative link between the candidate and voter and favoring voter participation throughout the electoral campaign in this medium.

In short, the proposed phased strategy meets the requirements for the implementation in the electoral processes in Ecuador since it has the necessary technological conditions such as mobile telephone services, smartphones, and internet in urban and rural areas. In addition, any political party or candidate can hire the services of the different proximity marketing providers according to their needs. On the other hand, there is no restriction according to the Electoral Organic Law in the use of this type of technological tools. Therefore, it can be used before, during and after any political campaign.

\section{References}

Alvarez, G. (2010). Principales efectos y ventajas del uso de las nuevastecnologías en campañas electorales. Cuadernos de Información y Comunicación, 15, 55-84.

Begoña, G. N. (2018). Fundamentos de la publicidad. Bógota: ESIC.

Castro, M. L. (2012). El marketing político en Estados Unidos: el caso Obama. Norteamérica, 7(1), 209-222. Retrieved from http://www.redalyc.org/articulo.oa?id=193724453008

Chaoyong, Q., Chunhong, L., \& Jie, W. (2019). Study on the evaluation of multimedia. Multimedia Tools and Applications, 1-14.

Consejo Nacional Electoral. (2019). Delegación Tungurahua. Retrieved from https://bit.ly/2JyupU1 
Consejo Nacional Electoral. (2019). Obtenido de Notificación $N^{\circ}$ 00071. Retrieved from https://bit.ly/2xTKBJb

Díaz Jiménez, O. F. (2015). Marketing político y profesionalización de las campañas electorales presidenciales del Partido Acción Nacional y del Partido de la Revolución Democrática, 1994-2006. Polis, 11(1), 119-168. Retrieved from https://bit.ly/30bszOQ

Dushinski, K. (2012). Mobile marketing handbook. CyberAge Books. Retrieved from ebookcentral.proquest.com

Escandell, C. (2017). Artyco, los apasionados del marketing que convierten a fans en clientes fieles. Cinco Dias. Retrieved from https://bit.ly/2TGR7wX

Falasca, K., Dymek, M., \& Grandien, C. (2019). Social media election campaigning: who is working for whom? A conceptual exploration of digital political labour. Contemporary Social Science, 14(1), 89-101. https://doi.org/10.1080/21582041.2017.1400089

Franco, M. A. M., \& Dader, G. J. L. (2009). La campaña de las elecciones generales de España en 2008, en el marco de la "americanización" de los procesos electorales. Madrid: Universidad Complutense de Madrid. Retrieved from https://bit.ly/2TFmcAW

Galarza, M. R. A. (2014). Clase política y medios: explorando el fenómeno de la publicidad política encubierta en México. Revista Mexicana de Ciencias Políticas y Sociales, 59(221), 51-76. https://doi.org/10.1016/S0185-1918(14)70815-3

García, B. V., \& D'Adamo, O. (2006). Comunicación política y campañas electorales. Análisis de una herramienta comunicacional: el spot televisivo. Polis, 2(2), 81-111. Retrieved from http://www.scielo.org.mx/pdf/polis/v2n2/1870-2333-polis-2-02-81.pdf

García, B. V., D'Adamo, O., \& Slavinsky, G. (2013). Comunicación Política y Campañas Electorales:Estrategias en elecciones presidenciales. Barcelona: Gedisa, S.A. Retrieved from ebookcentral.proquest.com

García, H. D. (2014). Las imágenes macro y los memes de internet: posibilidades de estudio desde las teorías de la comunicación. Paakat: Revista de Tecnología y Sociedad, 4(7).

García, M. A., \& Jaimes, L. L. (2010). Influencia del marketing electoral en la alternancia política del municipio de Toluca. Espacios Públicos, 13(29), 48-66.

Hassan, A. S. (2019). Evaluating the Marketing Communication Strategy of Volkswagen in Post-Crisis Period: Application of Image Repair Theory. International Journal of Marketing Studies, 11(2), 87. https://doi.org/10.5539/ijms.v11n2p87

Hassan, S. N. (2017). E-Marketing via Social Networking and Its Role on the Enhancement of Small Business Projects. International Journal of Marketing Studies, 9(1), 65. https://doi.org/10.5539/ijms.v9n1p65

Hernandéz, A. C. (2018). Campañas electorales presidenciales pragmáticas en México 2018. Revista Mexicana de Ciencias Políticas y Sociales(235), 327-352.

Jácome, S. V. L., Dueñas, E. F. X., \& Mera, A. M. (2015). Comunicación Electoral: La Transición de Marketing a capital político. San Gregorio. Retrieved from https://bit.ly/2YTPqSB

Lindon, D. (1977). Marketing político y social. Madrid : Tecniban.

López, R P., \& Mellado, C. (2018). Twitter as a space for interaction in political journalism. Dynamics, consequences and proposal of interactivity scale for social media. Communication \& Society, 32(1), 1-18. https://doi.org/10.15581/003.32.1.1-18

Maeshima, K. (2018). The Internet and the Americanization of Electoral Campaigning in East Asian Democracies. Political Campaigning and Communication, 1-25. https://doi.org/10.1007/978-3-319-63682-5_1

Martín, L. M. (2001). Voters and Mass Media during 1996 Spanish National Election Campaign: Selective Exposure or Media Influence? Communication \& Society, XIV(1), 51-70.

Medina, C. R. P., García, G. J., \& Jarrín, A. J. (2019). Marketing de proximidad: una herramienta de promoción de productos o servicios educativos. 3C Emresa. Investigación y pensamiento crítico , 8(2), 44-67. https://doi.org/10.17993/3cemp.2019.080238.44-67

Montoya, A. C. A., \& Boyero, S. M. R. (2013). El CRM como herramienta para el servicio al cliente en la organización. Visión de futuro, 17(1), 130-151. 
Moreno, C. (2012). Los efectos de las campañas electorales. Revista Española de Ciencia Política, 30, 55-74.

Moreno, M. D. X. (2017). Análisis de las campañas políticas a través de las redes sociales: Facebook y Twitter de Lenin Moreno, Guillermo Lasso y Cynthia Viteri candidatos a la presidencia de la república del Ecuador en los commicios del 19 de febrero de 2017. Sevilla : Universidad de Sevilla.

Moreno, C. (2012). Los efectos de las campañas electorales sobre el sentimiento de eficacaia política. Revista Española de Ciencia Política, 30, 55-74.

Norris, P. (1997). Politics and the Press: The News Media and Their Influences. Colorado: Lynne Rienner Publishers.

Palencia, R. (2016). El gran libro del comercio electrónico. Madrid: Bubok Publishing. Retrieved from https://ebookcentral.proquest.com/lib/utasp/detail.action?docID=5425576

Parra, B. A. Y. (2018). Análisis de la estretegia de campaña de Lenín Moreno hasta su discurso de posesión (Tesis de pregrado). Quito: Universidad de las Américas Quito.

Pérez, B. V. (2009). El político en la red social. Alicante: Editorial Club Universitario. Retrieved from ebookcentral.proquest.com

Perez, D. A. Y. (2013). Las campañas negativas en las elecciones de 2000 y 2006 en México. Revista Mexicana de Ciencias Políticas y Sociales, 222, 79-104.

Pérez, M. C. A. (2016). Comunicación y Marketing Político. Madrid: Centro de Análisis y Entrenamiento Político- CAEP.

Quesada, A. J. (2005). Marketing Político. Madrid : Partido Popular.

Ralph, F. W., \& James, B. P. (2010). Tracking online ad campaigns: A primer. Journal of Direct, Data and Digital Marketing Practice, 12(1), 69-82. https://doi.org/10.1057/dddmp.2010.19

Restrepo, E. N. (2015). La profesionalización de las campañas. Revista Española de Ciencia Política, 85-114.

Rippetoe, D., Pitchford, T., \& Zeto III, M. J. (2012). Systems and Methods for Delivering Proximity-Based Marketing Content to Mobile Devices. Patent Application No. 13/216,054.

Rivero, C. J., \& Huerta, M. R. (2017). Breve Manual de Marketing Político. México: Vanguardia Política Consultores S.C.

Salas, E., \& Jaramillo , A. (2018). Estudio de los factores de éxito de la campaña de marketing político de Donald Trump. Revista Observatorio de la Economía Latinoamericana.

Sánchez, A. (6 de Julio de 2016). Dan promociones a medida. Reforma. Retrieved from https://search.proquest.com/docview/1801884634? accountid=36765

Slimovich, A. (2017). La ruta digital a la presidencia argentina. Un análisis político e hipermediático de los discursos de Mauricio Macri en las redes sociales. Dixit(26), 24-43. https://doi.org/10.22235/d.v0i26.1321

Turban, E., King, D., Kyu Lee, J., Liang, T. P., \& Turban, D. C. (2015). Marketing and Advertising in E-Commerce. Suiza: Springer Texts in Business and Economics. Springer, Cham. https://doi.org/10.1007/978-3-319-10091-3_9

Valdez, Z. A., \& Huerta, F. D. (2009). Estrategias de comunicación en campañas electorales: El caso de la contienda presidencial de Estados Unidos. Contratexto, 17, 21-32. https://doi.org/10.26439/contratexto2009.n017.792

Visuri, A., Hosio, S., \& Ferreira, D. (2017). Exploring mobile ad formats to increase brand recollection and enhance user experience. MUM '17 Proceedings of the 16th International Conference on Mobile and Ubiquitous Multimedia, 311-319. https://doi.org/10.1145/3152832.3152834

Wahab, S., Wati Osman, S., \& Che Rose, R. (2012). Defining the Concepts of Technology and Technology Transfer: A Literature Analysis. International Business Research, 5(1). https://doi.org/10.5539/ibr.v5n1p61

\section{Copyrights}

Copyright for this article is retained by the author(s), with first publication rights granted to the journal.

This is an open-access article distributed under the terms and conditions of the Creative Commons Attribution license (http://creativecommons.org/licenses/by/4.0/). 